\title{
Impact of Goods and Service Tax (GST) on MSMEs in India
}

\author{
K. Beemabai, K. Krishnakumar
}

\begin{abstract}
The Micro, Small and Medium Enterprises (MSMEs) sector has been deliberated as the chief development driver of the Indian economy for the year(Sunil Mitra 2018). India is a predictable to appear as one of the important economies in the world over the next decade in the light of a positive political and economic scenario (Mc Kinsey 2017).The Micro, Small and Medium Enterprises (MSMEs) fragment is expected to play a significant role in the appearance of the Indian Economy. The development of this part is very decisive to meet the national imperatives of financial inclusion and generation of significant levels of employment across urban and rural areas of the country (Annual Report 2017-18). Micro, Small and Medium Enterprises (MSMEs) can be the backbone for obtainable and future of high growth business with both domestic and foreign companies. The present paper will focus on existing scenario and trends of MSMEs in India (ShriMadavLal 2015). There is equally important that the Micro, Small and Medium Enterprises (MSMEs) sector develops in all areas of agriculture, manufacturing and services sectors because each of these sectors will continue to be very relevant to the GDP growth as well as employment generation (ShriR.S.Gujral 2017). The Micro, Small and Medium Enterprises (MSMEs) sectors will act as a mechanism to bring about this socio-economic renovation. An attempt has been made in this study to find the sector wise contribution to GDP after Implementation of Goods and Services $\operatorname{Tax}(G S T)$.
\end{abstract}

Keywords : GST, MSMEs, Economic Growth, Indian Government.

\section{INTRODUCTION}

Goods and Service Tax (GST) combines both the current Central and State Taxes in the country into a solitary tax, thereby eliminating the dual taxation system and enabling a joint nationwide market (GST Council 2019). The Indirect tax is forced indirectly on goods and services tax. Goods and Service tax is a single comprehensive which will include all indirect taxes (CA RohitPithisaria 2019).The accomplishment of this tax allows the government to have an improve hold on the taxpayers, which in turn improve the complete tax scheme and has several other benefits (Ngwira.A(2016). SMEs have emerged as the principal employment-creating segment in India and have delivered stable growth through various sectors of our developing nation. Impact of Goods and Service Tax (GST) on MSME has been tremendous (Nagaraja, 2013). For Micro, Small and Medium Enterprises (MSME) the

Revised Manuscript Received on July 22, 2019.

K. Beemabai, K. Krishnakumar

PhD Research Scholar (RGNF Fellow) Email id:beema.sun.90@gmail.com Associate Professor of Commerce, Periyar University, Salem 636011.

Emailid:krishna30971@gmail.com business proprietors and producers are mandatory to pay various different taxes as per the laws and so, fulfilling all the tax-related documentations is running to different departments(Annual Report 2017-18). This reduces the changes of harassment and escalating their benefits. They are difficult to face the consumer point of view as well as traders.

Keating (2010) concluded that if the law elucidation based on the New Zealand court decision are referred to, it implies that assesses will find it difficult to evade the law. Vasnthagopal (2011) A Big leap in the Indirect Taxation System is impact of Goods and Services Tax on various sectors of economy and new impetus of India's economic change. Ciobanasu (2012) to trace indirect tax by in very temperament is easier to govern. It is concluded that both the taxes are important for overall intensification of the every country. Agogo Mawuli (2014) Goods and Services Tax is not good for low-income countries and does not provide broad based growth to poor counties. If still these countries want to implement GST then rate of GST should be less than $10 \%$ for growth. Garg (2014) Goods and Services Tax is Impacts creates on Indian Tax Scenario and it will strengthen out free market economy. Satay Poddar (2014) Goods and Services Tax Reforms is Intergovernmental Consideration in India and found that GST introduction will provide simpler and transparent in India. Amanuddin Sham suddin (2016) Goods and Services Tax impact on business in SMEs to create better policies on Taxation in general. Practionners or business owners also could benefit from the findings in dealing with their own taxation matter. Subrahmanya Bharetal., (2017) examined that Goods and Services tax is Single Tax comes under uniform market for all corporate sectors and the Indian Economy. Shashanka (2018) Goods and Services Tax idea alongside noteworthy of Indian GST taxation system rates with VAT and furthermore exhibited top to bottom scope in regards to points of interest to different segments of Indian Economy.

The Concepts of Goods and Services Tax is biggest tax reforms in throughout the world, but India have been taking small steps to improve the taxation system. The Indention of Research is after implementation of Goods and Services Tax

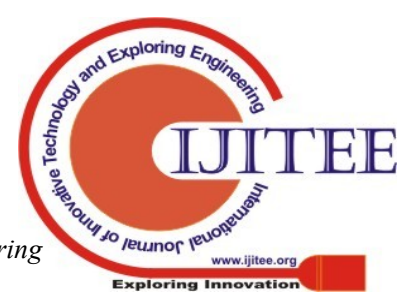


(GST) creates any impacts on Indian Economy as well as GDP growth. Particularly if since to be greater impact on MSMEs. Therefore, it is essential to know the impact of GST after implementation on MSMEs in India.

\section{OBJECTIVE OF THE STUDY}

The study has been geared towards achieving the following objectives:

1.To Study the conceptual background and the evolution of Goods and Services Tax on MSMEs in Indian Scenario.2.

2.To know the impact of Goods and Services Implementation on Indian Economy and its challenges of MSMEs Sectors.

\section{DATA SOURCES}

An attempt to have been made on the basis of secondary data sourced from various Journals, Magazines, Articles and Media reports. Available secondary data was extensively used for the study.

- Fourth All India Census Report of MSME (2011-12 to 2017-18)

- Annual Report of MSME (2011-12 to 2017-18) and The Gazette of India (16 ${ }^{\text {th }}$ June, 2006)

-Websites of Ministry of Micro, Small and Medium Enterprises.

- Entrepreneurs Memorandum Part-II data on MSME sector (2007-2015)

\section{GOODS AND SERVICE TAX BILL IN INDIA}

The Goods and Services Tax (GST) is widespread on a national scale indirect tax on manufacture, sale and consumption of goods and services tax. The input credits tax paid at each stage will be calculated on the based on indirect tax. However, at the national level for proposed in first introduced goods and services tax was raised by the then (Finance Minister P.Chidambaram) in his budget speech. In this bill is known as the (Constitution $122^{\text {nd }}$ amendment) bill or the Goods and Service tax bill. The new (Constitutional $122^{\text {nd }}$ amendment) bill will confer power to parliament and state legislature to make laws for levying Goods and Service tax. Indirect taxes will be a major contribution in the GDP in India as to Compared to Most of the countries forming part of the study.

Impact of Goods and Services Tax (GST) on the Indian Economy

The Goods and Service Tax (GST) was implemented in India from $1^{\text {st }}$ July 2017, in the order of 12 years after being first proposed in the (Finance Minister P.Chidambaram Parliament in 2006 by) the during the UPA rule. The Tax overhaul is one of the biggest reforms in India's tax code since India's affirmation on independence in 1947. On the eve of first anniversary of this landmark reform, we crack to review its performance and impact on the various drivers of the Indian economy.

The Micro, Small and Medium Enterprises (MSMEs) were just recuperating from the demonetization drive implemented in November 2016 when GST was implemented in July 2017 (Economic times 2017). The biggest impact of Goods and Services Tax (GST) in the short term has been felt by this group. MSMEs has increased from 58 days to 70 days, increasing their working capital requirements. Similarly, MSME export houses have also had to bear the substance of a delay in processing of tax credits.

Positive Impact of Goods and Services Tax (GST)on MSMEs

- Low Rates Taxes: Industries having a turnover have to pay levies at lower rates, thereby being paid gigantic relief from tax burdens.(http://webtel.in/.)

- Starting business becomes easier: Uniform Goods and Services Tax (GST) will normalize the process due to which the price insightful MSMEs will be burdened.(http://webtel.in/.)

- Reduction in logistics cost and time: This diminished costs to retaining large stocks due to ease in free movement of goods.(http://webtel.in/.)

- Creating a Uniform Platform: Thus removing all tax differentiation and bringing small and medium businesses to par with large-scale industries.(http://webtel.in/.)

- Increased Reach to Customers: Small and Medium business to reach their potential customers across India, which surges the attainment charge of products for the consumers. The implementation of Goods and Services Tax (GST) will prevent that.(http://webtel.in/.)

Negative Impact of Goods and Services Tax (GST)on MSMES

- The Burden of Lower Threshold: Goods and Services Tax (GST) bill has for North-Eastern states, due to which any service provider or retailer is subject to the tax levy. Now, as a doorstep is low, most MSMEs have to pay a lump sum of their investment towards tax in the near, foreseeable future. (http://webtel.in/.)

- Lack of Tax Differentiation for Luxury items and services: Tax neutrality, which is an increase in the financial gap between the rich and poor and is not a model situation for MSMEs to compete and flourish against large industries.(http://webtel.in/.)

- Selective Tax Levying: Its creates further fissure and does not support the 'Unified Market' of Goods and Services Tax (GST). (http://webtel.in/.)

- Excess Working Capital Requirement: The quantum of impact will vary depending on credit cycle to

Published By: 
customer, quantum of stock transfer.(http://webtel.in/.)

- The burden of higher tax rate for Service Provider: The circumstances in the service sector will be the concept of Centralised Registration.(http://webtel.in/.)

- Realignment of Purchase and Supply Chain: Thus sourcing strategies will change on account of Goods and Services (GST) credit mechanism. (http://webtel.in/.)

- Dual Control: As a result of this, small trader's production in both goods and services will be dual secretarial control both by Central and State. (http://webtel.in/.)

\section{Table : 1}

MSME Definition in India (Micro Small Medium Enterprise Development Act, 2006)

\begin{tabular}{|c|c|c|}
\hline \multirow[b]{2}{*}{ Type } & \multicolumn{2}{|c|}{ Enterprises } \\
\hline & $\begin{array}{c}\text { Manufacturing Sector } \\
\text { (Investment In Plants } \\
\text { and } \\
\text { Machinery) }\end{array}$ & $\begin{array}{c}\text { Service Sector } \\
\text { (Investment in } \\
\text { Equipments) }\end{array}$ \\
\hline Micro & Up-toRs.25 lakhs & Up-toRs.10 lakhs \\
\hline Small & $\begin{array}{l}\text { More thanRs. } 25 \text { lakhs } \\
\text { toRs. } 5 \text { crores }\end{array}$ & $\begin{array}{l}\text { More thanRs. } 10 \\
\text { crores }\end{array}$ \\
\hline Medium & $\begin{array}{l}\text { More thanRs. } 5 \\
\text { croresup- toRs. } 5 \text { crores }\end{array}$ & $\begin{array}{l}\text { More thanRs. } 2 \\
\text { croresup-toRs. } 5 \text { crores }\end{array}$ \\
\hline
\end{tabular}

Table :2
(Source: The Gazette of India, $16^{\text {th }}$ June,2006)

The Ministry of MSME is playing an important role in employment cohort, livelihood opportunities and upgrades the competitiveness of MSME in the tainted economic pitch. As intensification route must be always pro- poor or pro-disadvantaged section of the society The MSMEs are widening their domain across sectors of the Economy, Producing assorted range of products and services to meet anxiety of domestic as well as global markers.(Annual ReportofMSME2016-2017)

Contribution of MSMEs in Total GDP in India

\begin{tabular}{|c|c|c|c|c|c|}
\hline \multirow{2}{*}{ Sl.No } & Year & \multicolumn{3}{|c|}{ Share of MSME's Sector in Total GDP in \%) } & $\begin{array}{c}\text { Total } \\
\text { GDP }\end{array}$ \\
\hline & & Agriculture & $\begin{array}{c}\text { Manufacturing } \\
\text { Sector in MSMEs }\end{array}$ & $\begin{array}{c}\text { Service } \\
\text { Sector in } \\
\text { MSMEs }\end{array}$ & in (\%) \\
\hline 1 & $2011-12$ & 18.73 & 15.25 & 16.35 & 5.2 \\
\hline 2 & $2012-13$ & 8.99 & 6.85 & 14.65 & 6.4 \\
\hline 3 & $2013-14$ & 16.67 & 2.21 & 13.65 & 4.5 \\
\hline 4 & $2014-15$ & -0.03 & 6.89 & 9.49 & 7.5 \\
\hline 5 & $2015-16$ & 0.76 & 8.22 & 9.84 & 8 \\
\hline 6 & $2016-17$ & 4.37 & 5.77 & 7.87 & 7 \\
\hline 7 & $2017-18$ & 17.1 & 16.7 & 53.9 & 6.5 \\
\hline
\end{tabular}

((Source: Ministry of Statistics and Programme Implementation (2018-2019) Planning Commission, Govt., of India)

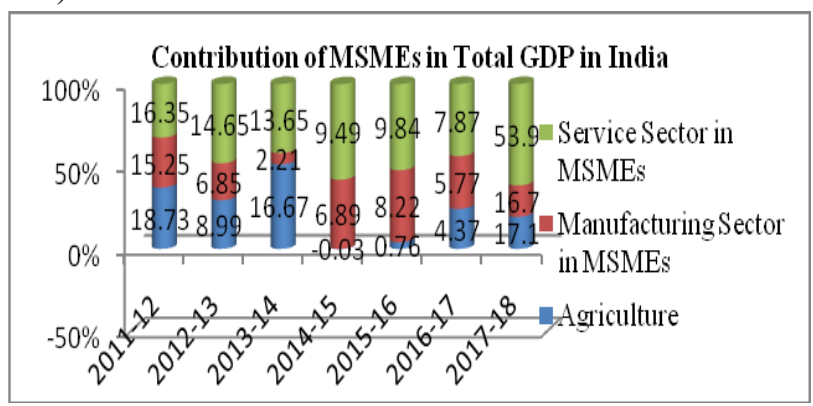

Figure: 1

The MSMEs are widening their domain across sectors of the Economy, Producing assorted range of products and services to meet anxiety of domestic as well as global markers.

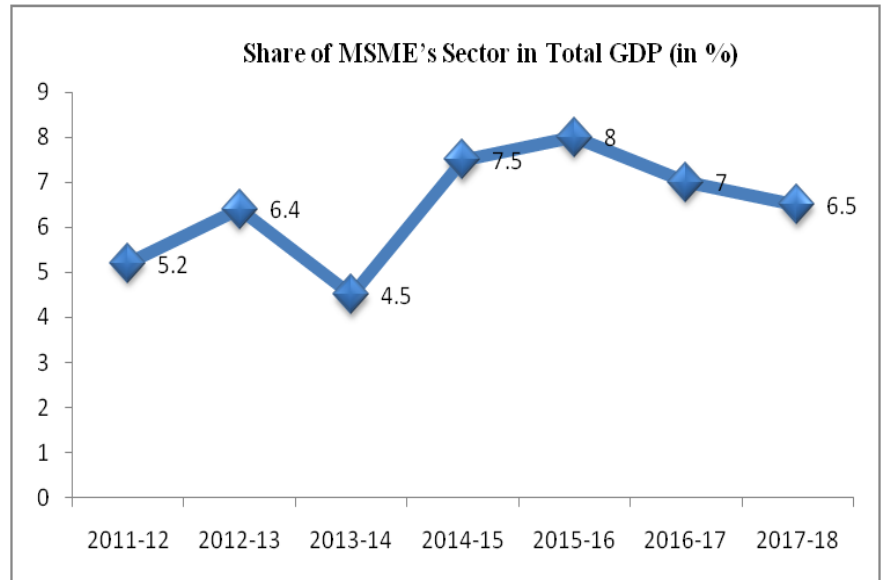

Figure :2 


\section{Gross Domestic Product (GDP)}

Gross Domestic Product is pet by adding taxes on products, net of subsidies on products to GVA at basic price. There as on may be that people are more lying face down to invest in service sectors slightly manufacturing units.(Economic Survey2017-2018)

Table: 3

State- Wise Distribution of Enterprises

\begin{tabular}{|r|l|c|c|}
\hline \multirow{2}{*}{ SI.No } & \multirow{2}{*}{ State/UT } & \multicolumn{2}{|c|}{$\begin{array}{c}\text { Estimated Number of } \\
\text { MSME's }\end{array}$} \\
\cline { 3 - 4 } & & $\begin{array}{c}\text { Number } \\
\text { (in lakh) }\end{array}$ & $\begin{array}{l}\text { Share (in } \\
\text { \%) }\end{array}$ \\
\hline 1 & Uttar Pradesh & 89.99 & $14 \%$ \\
\hline 2 & West Bengal & 88.67 & $14 \%$ \\
\hline 3 & Tamil Nadu & 49.48 & $8 \%$ \\
\hline 4 & Maharashtra & 47.78 & $8 \%$ \\
\hline 5 & Karnataka & 38.34 & $6 \%$ \\
\hline 6 & Bihar & 34.46 & $5 \%$ \\
\hline 7 & Andhra Pradesh & 33.87 & $5 \%$ \\
\hline 8 & Gujarat & 33.16 & $5 \%$ \\
\hline 9 & Rajasthan & 26.87 & $4 \%$ \\
\hline 10 & Madhya & 26.74 & $4 \%$ \\
\hline & Pradesh & & \\
\hline
\end{tabular}

(Source: Annual Report (2017-18) Department of Industries and Commerce, New Delhi)

Calculations are done by the Author; Last Census on MSMEs Published Annual report on Tamil Nadu has occupied first position in terms of EM-II filled by on MSME in 2014-15 but now in the position of Third Place of Distribution share in Enterprises. Now a day's Tamil Nadu having down word in the movement. The Contribution of MSME segment to the GDP in some of the global economies is in the 25 to 60 percent range (Annual Report 2017-18).

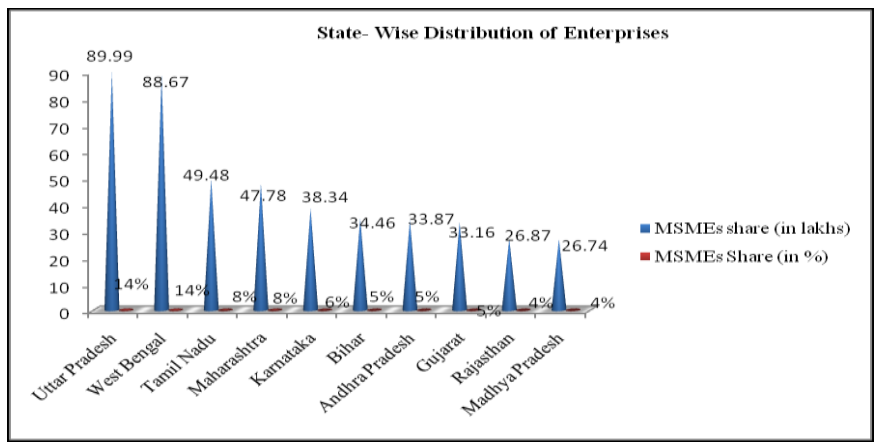

Figure: 4

\section{Comparison of MSMEs Export to Total Exports}

The MSMEs Sector in India is contributing more than 40 percent to Exports. It can be seen from the table.

Table: 4 Share of MSMEs Exports in Total Exports (Amount in USD Million)

\begin{tabular}{|c|c|c|c|c|c|}
\hline & Year & Total Exports & $\begin{array}{c}\text { Exports by } \\
\text { MSMEs }\end{array}$ & $\begin{array}{c}\text { Share of MSME } \\
\text { Exports in (\%) }\end{array}$ & $\begin{array}{c}\text { Growth rate of } \\
\text { MSME Sectors }\end{array}$ \\
\hline 1 & $2011-12$ & 283847 & 146595 & $22 \%$ & $4.40 \%$ \\
\hline 2 & $2012-13$ & 300400 & 127992 & $43 \%$ & $5.60 \%$ \\
\hline 3 & $2013-14$ & 314415 & 133313 & $42 \%$ & $9.10 \%$ \\
\hline 4 & $2014-15$ & 310352 & 138896 & $45 \%$ & $8.56 \%$ \\
\hline 5 & $2015-16$ & 262291 & 130768 & $50 \%$ & $7.62 \%$ \\
\hline 6 & $2016-17$ & 275852 & 137068 & $50 \%$ & $7.10 \%$ \\
\hline 7 & $2017-18$ & 303376 & 147390 & $49 \%$ & $6.40 \%$ \\
\hline
\end{tabular}

(Source: RBI \& Press Information Bureau/Directorate

General of Commercial and

Statistics 2017-18. (DGCIS)

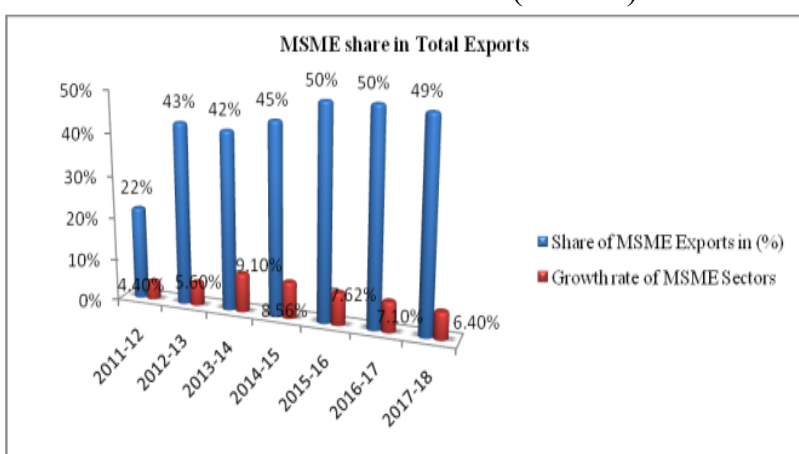

Figure : 5

Calculations are done by the Author; Last Census (2017-18) on MSMEs Published Annual report on Exports contributions of the services, manufacturing and agriculture to the overall exports from India is literally skewed. After execution of

Goods and Service Tax (GST) export share of MSMEs shows that down the exports level compare with the previous year exports of India.

Table:5

Distribution of Employment in Rural and Urban

\begin{tabular}{|c|c|c|c|c|}
\hline \multirow{2}{*}{$\begin{array}{c}\text { Broad Activity } \\
\text { Category }\end{array}$} & \multicolumn{3}{|c|}{ Employment (in lakh) } & \multirow{2}{*}{ Share in (\%) } \\
\cline { 2 - 4 } & Rural & Urban & Total & \\
\hline Manufacturing & 186.56 & 173.86 & 360.41 & 32 \\
\hline Trade & 160.64 & 226.54 & 387.18 & 35 \\
\hline Other Services & 150.53 & 211.69 & 362.22 & 33 \\
\hline All & $\mathbf{4 9 7 . 7 8}$ & $\mathbf{6 1 2 . 0 9}$ & $\mathbf{1 1 0 9 . 8 1}$ & $\mathbf{1 0 0}$ \\
\hline
\end{tabular}

(Source: Annual Report (2017-18)

Published By: 
Distribution of Employment in Rural and Urban (in Lakhs)

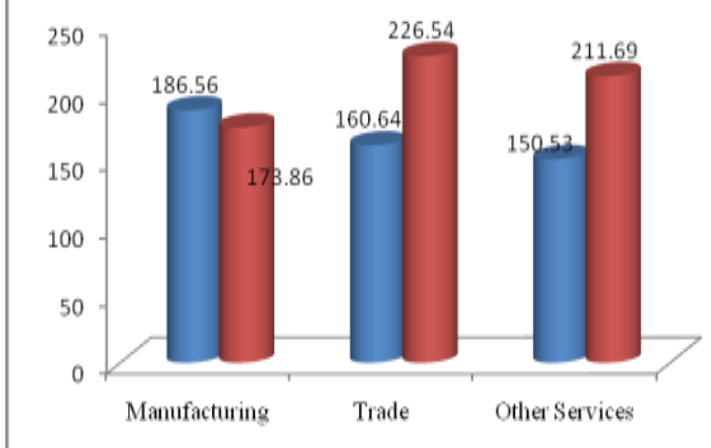

Figure : 5

Calculations are done by the Author; Last Census (2017-18) on MSMEs Published Annual report on increase in MSMEs Contribution to the GDP is probable to employment over the 50 percent over the next decade. Table: 5andFigure:5 shows the distribution of MSMEs activity wise (National Sample Survey(NSS)MSMEs who are presently not registered need to made part of the formal MSMEs eco system. It is also decisive to see the plenty growth is meet across Manufacturing, trade and Other services segments to make certain holistic and untiring overall economic growth of the country.

Table: 6

Distribution of Employment in MSMEs on Rural and Urban

\begin{tabular}{|c|c|c|c|c|c|}
\hline Sector & Micro & Small & Medium & Total & $\begin{array}{c}\text { Share in } \\
\text { (\%) }\end{array}$ \\
\hline Rural & 489.3 & 7.88 & 0.6 & 497.78 & $45 \%$ \\
\hline Urban & 586.88 & 24.06 & 1.16 & 612.1 & $55 \%$ \\
\hline All & $\mathbf{1 0 7 6 . 1 9}$ & $\mathbf{3 1 . 9 5}$ & $\mathbf{1 . 7 5}$ & $\mathbf{1 1 0 9 . 8 9}$ & $\mathbf{1 0 0}$ \\
\hline
\end{tabular}

(Source: Annual Report (2017-18)

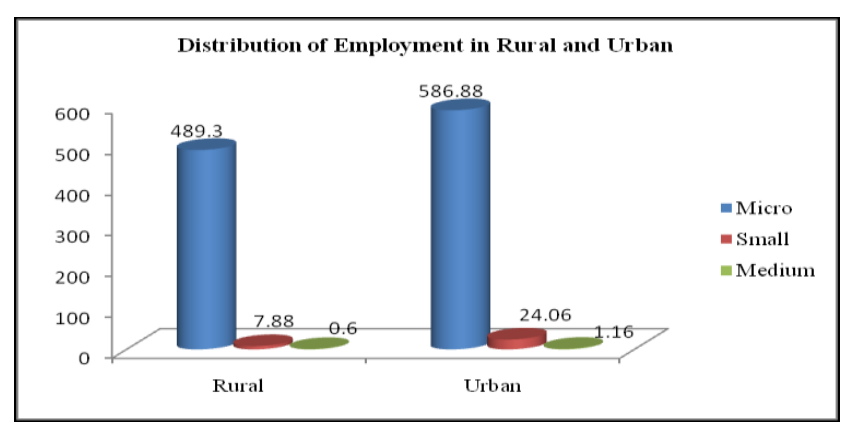

Figure: 6

Calculations are done by the Author; Last Census (2017-18) on MSMEs Published Annual report on increase in MSMEs Contribution to the GDP is approaching to employment over the 50 percent over the next decade. As per the National Sample Survey (NSS) conducted during the period2017-18,Table: 6andFigure: 6 show the circulation of MSMEs activity wise. It is also decisive to see the profusion growth is meeting across Manufacturing, trade and other services segments to make certain holistic and untiring overall economic growth of the country.

Table :7 Growth Rate of MSME Sector in Comparison with the Overall Industrials Sector

\begin{tabular}{|c|l|c|c|}
\hline SI.No & Year & $\begin{array}{c}\text { Growth } \\
\text { Rate } \\
\text { MSME } \\
\text { Sector in } \\
(\mathbf{\%})\end{array}$ & $\begin{array}{c}\text { Overall } \\
\text { Industrials } \\
\text { Growth Rate } \\
\text { in (\%) }\end{array}$ \\
\hline 1 & $2011-12$ & 4.4 & 7.8 \\
\hline 2 & $2012-13$ & 5.6 & 6.8 \\
\hline 3 & $2013-14$ & 9.1 & 6.8 \\
\hline 4 & $2014-15$ & 8.6 & 6.6 \\
\hline 5 & $2015-16$ & 7.6 & 6.6 \\
\hline
\end{tabular}

(Source: Based on data for CSO Economic Survey 2017-18, Volume:2)

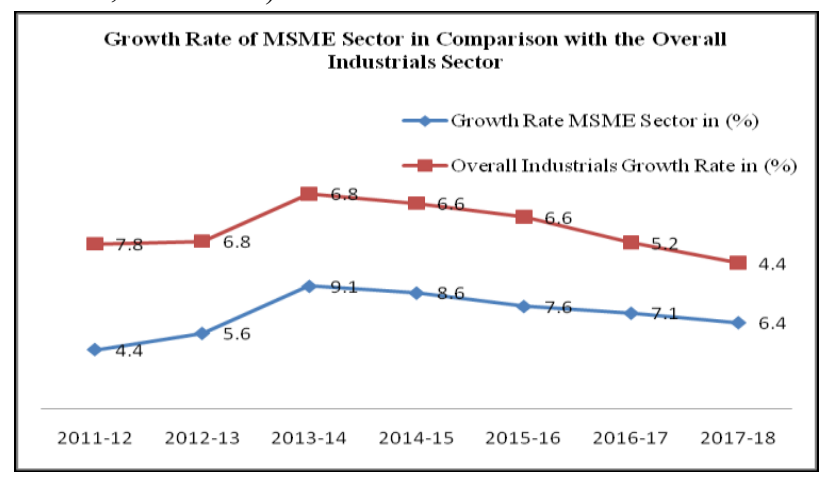

Figure: 7

As per the manifestation of Industrial Production (IIP), the industrial output increased by 4.4 percent during period of previous year. The Growth of 3.9 percent during April-November 2017-18 over the corresponding period of previous year. India has least 30 ranks so contrast previous rank of 130 in the World Bank's latest Doing Business Report 2018.

\section{CONCLUSION}

The Current Economic scenario, some of the national vital to propel India into the next wave of growth, on generating new employment opportunities of special segments such as physically challenged traditional industries etc. Micro Small Medium (MSMEs) is in the real sense of the engine of Economic growth of every developed and developing country. MSMEs often precisely termed the engine of growth for India. Financial inclusive growth to its lower income growth of rural and urban economies. This way to be get better the pretty and widening of Export capabilities and becoming globally creating competitive developing the global technologies and innovation. It develops and motivates the "Make in India". To promote the culture of modernism and entrepreneurship.

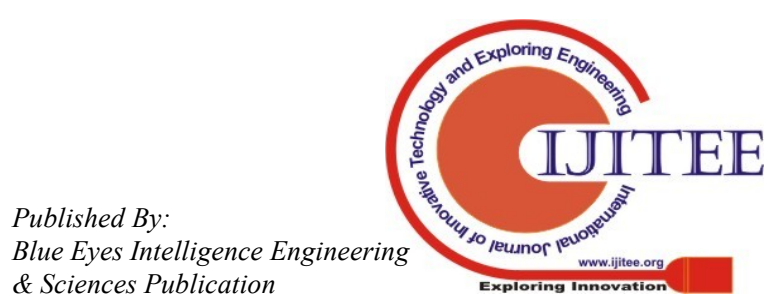


Global competiveness and admittance to technology on India should create an environment for MSMEs to partner with their global business and evolve to global on innovation adapting new technologies and to attention to quality.

\section{REFERENCES}

1. Agogo Mauli (2014) Goods and Service tax in India: problems and prospects, Asian Journal of Management Research, Volume 6 Issue 3, Research Article ISSN: 2229-3795.Page No: 504-510.

2. Annual Report (2017-18) Department of Industries and Commerce, New Delhi).

3. Annual Report of MSME (Year wise 2017-2018).

4. Annual Report Economic Survey (2017-18).

5. Business world (2018-19).

6. CA Rohit Pithisaria (2019) Proscenia Economics and Finance Volume 31, 2015, Pg No: 373-379.

7. Ciobanasu (2012) "Contribution of taxes to the making up of budget revenue in Economic Growth", Journal of knowledge Management Economics and information Technology Vol.2 (Issue 6) Pg1-12.

8. Deccan Chronicle and The Economic Times (2019).

9. Fourth All India Census Report of MSME. (Annual Report 2017-18).

10. Keating S (2011) "Goods and Services Tax: will the proposed indirect tax Reform change Business and Tax Dynamics in India", NUJS law Review Vol.4 Pg 625 -638.

11. K.Beemabai and Dr.K.Krishnakumar (2019) International Journal of Management Technology and Engineering, Vol-IX, Issue-IV April 2019. Impact factor 6.3.

12. Goods and Services Tax (GST) 2017-18 Economy and Policy

13. Mc Kinsey (2017) RBI \& Press Information Bureau 2017-18 (DGCIS).

14. Ministry of Statistics and Programme Implementation (2018-2019) Govt. of India.

15. Ngwira (2019) Results of a Nationwide Survey on Micro, Small, and Medium Enterprise sin Malaw.1993.

16. Sataty Poddar (2014) Economic Survey (2017-18) Volume-2.

17. Shashanka (2018)Economic Times (2019)

18. ShriMadavLal (2015) RBI \& Press Information Bureau 2017-18 (DGCIS)

19. ShriR.S.Gujaral (2017) Ministryof MSME, Entrepreneurs Memorandum Part-II data on MSME sector (2007-2015).

20. Subrahmanya Bhat (2017) "Revolution in Indian Tax system Goods and Service Tax", International Education \& Research Journal E-ISSN NO: 2454-9916 Vol.3, ISSUE: 5.

21. Vasantha Gopal (2011) "GST in India: A Big Leap in the Indirect Taxation System", International Journal of Trade, Economics and Finance Vol-2, Issue:2, Pp No:144-146.

22. Wikipedia-Goods and Services Tax (GST).

\section{Website}

1. http://economices.indiatimes.com/sme-sector/most-powerful-engineindias-growth.

2. http://www.indiastat.com/SOCIOPDF/130/fulltext.pdf

3. www.greengst.com

4. www.academia.edu.

5. http://www.quora.com

6. www.mapsofindia.com

7. www.gstindia.com

8. http://www.thehindu.com/news/national/tamil-nadu/msmes-worriedover-poor-industrial-climate/article23796438.ece.

9. http://www.webtel.in/.

10. www.demsme.gov.in 